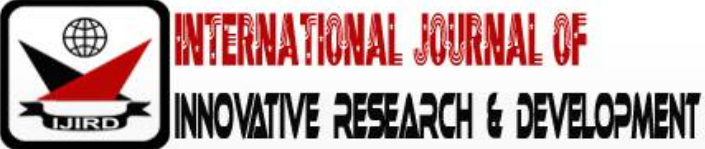

ISSN 2278 - 0211 (Online)

\section{Exploring the Relationship between Social Studies and Other Social Science Subjects for Effective Capacity Building and National Development}

\author{
Dr. Essien, Essien Ekpenyong \\ Senior Lecturer, Department of Social Science Education \\ University of Calabar, Nigeria \\ Dr. Gimba, Joseph \\ Chief Lecturer, Department of General Studies, \\ Taraba State College of Agriculture, Nigeria \\ Ekpoto, Ekpoto Agbor \\ Assistant Lecturer, Department of Social Science Education, \\ University of Calabar, Nigeria
}

\begin{abstract}
:
Social Studies provide opportunities for students to know the variables in the environment and how to interact with it and develop the attitudes, skills and knowledge that will enable them to become engaged, active, informed and responsible citizens. Recognition and respect for individuals and collective identity is essential in a pluralistic and democratic society. Social Studies helps students develop their sense of self and community inter-independence, encouraging them to affirm their place as citizens in an inclusive, democratic society. The relationship between Social Studies and certain Social Science subjects like Psychology, Political Science, Geography, History Sociology, Economics, History, Science and Technology and Anthropology brings out the eclectic nature of Social Studies for effective human capacity-building and national development.
\end{abstract}

Keywords: Social studies, social science, relationship, capacity building, national development

\section{Introduction}

Social Studies is a lifelong course of learning, which involves human interactions with his physical and social variables. It is so unique that it captures all human endeavours and his existence. Social studies are viewed as the integrated study of the social sciences and humanities to promote civic competence through practical applications of knowledge and skills.

This paper will discuss social studies and its relationships with other social science subjects and how concepts from Political Science, Psychology, Geography, Sociology, Economics, History, Anthropology and other social science subjects that make meaning in social studies.

\section{Conceptual Clarification}

\subsection{Social Studies Education}

Scholars and researchers view Social Studies as an interrelated discipline which subsumes other fields in the Social Sciences. Edinyang, Unimke, Ubi, Opoh and Iwoke (2015) posited that Social Studies is a term used to describe the broad study of various fields of studies which involved human behaviour and social interaction. These interactions have to deal with human organizing themselves by embracing the diversity of culture in the society.

In the same vein, the National Council for Social Studies, (NCSS, 1992) defined Social Studies as the integrated study of the Social Sciences and humanities to promote civic competence. Within the school programme, Social Studies provides coordinated, systematic study drawn upon such disciplines as anthropology, archaeology, economics, geography, history, law, philosophy, political science, psychology, religion, and sociology, as well as appropriate content from the humanities, mathematics and natural sciences. http:/ / www.education.com/ reference/ article/ definitions-social-studies/ Though, there has been a debate on the appropriate definition of Social Studies, Social Studies is the interdisciplinary integration of Social Science and humanities concepts for the purpose of practicing problem solving and decision making for developing citizenship skills on critical Social issues (Zarrillo, 2013).

According to Francis (2008), Social Studies may be more difficult to define than in a single discipline such as history or geography, precisely because it is multidisciplinary and interdisciplinary, and because it is sometimes taught in 
one class (perhaps called "Social Studies") and sometimes in separate discipline-based classes within a department of Social Studies.

However, Social Studies as a field of Study it is designed to promote civic competence and it is integrative, incorporating many fields of endeavour. Social Science is an umbrella concept and a field of study or academic discipline which envelops a number of discrete disciplines in their discreteness or separateness such as Political Science, Sociology, Economics, Psychology, Geography and many others (Meziobi \& Meziobi, 2015).

Although, Social Science as a subject can be view as that, which is generally regarded to include Psychology, Sociology, Anthropology, Economics and Political Science, consists of the disciplined and systematic Study of Society and its institutions, and of how and why people behave as they do, both as individuals and in groups within society. At a minimum it would appear that to be "scientific" entails a systematic and disciplined method of acquiring knowledge, and that knowledge must be verifiable knowledge (McQuail, 2005).

The Social Sciences encompass diverse concerns of society that include a wide range of content drawn from the disciplines of History, Geography, Political Science, Economics, and Sociology. The selection and organisation of material into a meaningful Social Science curriculum, one that will enable students to develop a critical understanding of society, is therefore a challenging task. The possibilities of including new dimensions and concerns are immense, especially in view of the students' own life experiences.

Relationship is a Social concept that is interaction geared as Social or group life is predicated on interactions or inter-personal or inter-group relationship. This is seen as a linkage between two or more variables that can either be positive or negative. But in social terms, is it link to interactions that wield positive results (Meziobi\& Meziobi 2015).

All knowledge in Social Studies and Social Science is (1) knowledge of human beings, including their culture and products, and (2) knowledge of natural environment. Human culture has been changing, and knowledge about it has been gradually accumulating ever since far distant time when humans first assumed their distinctively human character. But until rather recent times, this knowledge was not scientific in the modern sense. Scientific knowledge is knowledge that has been systematically gathered, classified, collated, and interpreted. It is concerned with learning the concepts and applying those concepts to particulars, rather than just learning a vast amount of information (Slater, 2004).

\subsection{Objectives of Social Studies Education Include}

Create awareness of and sensitivity to man's environment.

- Influence man's attitudes positively to social, cultural political values and total environment.

- Enable men to acquire skills for solving societal and environmental problems.

- Equip men with the basic understanding of the knowledge of the total environment.

- Encourage voluntary participation in social and civic duties while developing the sense of responsibility (Ogunbameru, 2006).

Other roles played by Social Studies Education include:

- The development of National consciousness and commitment as necessary ingredients for nation building.

- The inculcation of social value and skills for active social life.

- The development of intellectual skills, knowledge and abilities for better understanding of the immediate and remote environment.

- Developing rational thinking ability for practical social life.

- Identifying and solving problems using problem solving techniques.

- Promoting value awareness and utilization of some values in tackling dynamic problems in the society (Ogunbameru, 2006).

According to Augsburg (2006), Social Studies programmes reflect the changing nature of knowledge, fostering entirely new and highly integrated approaches to resolving issues of significance to humanity. Over the last fifty years, the scholarly community has begun to rethink disciplinary boundaries and encourage more integration across disciplines. This process has been spurred by pressures such as the following:

Social issues, such as poverty, crime, and public health, are increasingly understood to transcend the boundaries of disciplines, cultures, and nations. As these issues grow increasingly complex, the work to develop solutions demands an increasingly integrated view of scholarly domains and of the world itself. Many scholars now define themselves by the issues and problems they address and use several disciplines to inform their work. Entirely new departments and programmes reflect this development.

Technology provides increasingly easy access to data bases that are cross-disciplinary and multidisciplinary as well as to scholarship in many disciplines. Scholars increasingly consider themselves to be members of the international academic community and share findings regularly across intellectual and geographic boundaries.

\subsection{Components of Social Studies Education}

All the disciplines that constitute the Social Sciences all together are referred to the Social Sciences or Social Science discipline. There is no agreement among Social Scientist as to what discipline constitute the Social Science, according to Okpaga (2013) in Mezieobi (2015) are Economics, Geography, Political Science, Psychology, Sociology and Demography.

Subjects like History, Anthropology, some disciplines in the humanities such as Law, Linguistics, Religion, Philosophy and Criminology have been added. Subject in applied Social Sciences too are included as Social Science, Accounting, Business Administration, Banking and finance. Education, Communication Studies, Environmental Studies, Development Studies and Computer Science are included as Social Science (Okpaga,2013). 
From the definitions of Social Studies, it is clearly observed that the component of Social Science is embedded in the definition, the NCSS definition points out that it is the various disciplines of the Social Sciences and humanities that provide the content for what is taught in Social Studies the component is as follows; Political Science, Psychology, Geography, Sociology, Economics, History and Anthropology.

\subsection{The Concepts of Social Sciences and Its Objectives}

The term Social Science is a very broad area that covers discipline like Economics, Geography, Political Science, Psychology, History and Sociology. This term has been defined variously by different authors and scholars. For example, Aliegba (2004) described Social Science as a discipline that deals with socio-cultural aspect of human behaviours. The oxford advance learner's dictionary $7^{\text {th }}$ edition (2006) described Social Science as the study of people in the society or a particular subject connected with the study of people in society, for example Geography, Economics or Sociology. In the same view Okpaga (2003:5) defined Social Science as the discipline of study that attempt to give an understanding and explanation of human activity in the context of social relations, social groups and institution. All the definitions x-rayed point out to the fact that social science deals with human behavior and relationship in society.

Social Studies as a course is about man and his social, political etc and behaviour and has it root from the Social Science subjects this is what had made it an eclectic subject. The relationship Social Studies has with other Social Sciences is important for the general growth, development and process of man in his different activities and relationship.

Political Science is the study of social arrangements to maintain peace and order within a given society. It deals with government, and its interests are: Politics, Laws, Administration, International relations and theory of the nature and functions of the state. It has both a philosophical and a practical base. It examines the theory of systems of government, but it also Studies actual practices by which government, Taxes, Prohibits, Regulates, Protects and Provides services. Lawal (2002) in Gajere (2015) postulated that the integration of Political Science concept in Social Studies provides the learners with the chances of learning about people's attitude, idiosyncrasies and value judgment can be influence. The integration of some concepts from political science into Social Studies curriculum content will enable the learner to understand that all societies make policies or law about how the people should live together in peace and harmony. This, also, exposes the students to the understanding that decisions, policies and laws made for and by a given society are a reflection of their values, beliefs and traditions.

Psychology deals with the mind and personality of the individual. It is a social science because humans are social creatures. Saul (2011) defined psychology as a scientific study of the mine and behaviour. Psychology is seen as the general Study of behaviour. Social Psychology is a facet of psychology that deals primarily with the way the social interaction affects the individuals involved. Social psychologies are interested in how individuals are affected by social situation. It focuses on the individual and physical processes, such as: biological structure, development and maturation of the various branches of psychology, the most relevant to Social Science is Social psychology. Social psychology is the Study of the individual's behavior as it influences and is influenced by the behaviour of others. Some specific topics that interest psychologists and social psychologists are: Socialization, Environment and heredity, Adjustment and maladjustment. These social scientists deal with natural phenomena such as emotion, memory, perception, and intelligence

Irikana and Ibeh (2014:93) in Mezieobi (2016) noted that Psychology Studies man, his mental behaviours, activities and motivations. Psychology being a component of Social Studies Education could assist the learners to gain the insight that behaviour can be influence by a lot of factors, such as, one's society, environment, peers, family upbringing education level etc.

Geography is the study of the natural environment and how it influences Social and cultural development. According to Joseph (2008) what connections does geography has with Social Studies is that Geography is as much a Social Science as it is a physical science. It is impossible to separate the two. The physical environment is affected by the cultural environment, and the cultural environment is shaped by the physical environment. Some of the concerns of geography are: Ecology, Climate, Resources, Accessibility, Demography, Geography has practical applications manifest in Maps, Trade patterns, Industrial and agricultural decisions, Settlement of population, Aggression and acquisition. This discipline affords the Students the opportunity to Study the functional relationship between human beings, land characters of areas and condition as well as the processes of the earth surface that is air, water and terrain (Gajere 2015). In the same vein Lawal (2002b) posited that the discipline assists learners to understand alternatives available for future human settlement and demonstrate them through maps, physical and human patterns on the earth surface. The acquisition of geographic knowledge and skill will help Social Studies students to make informed decision about their physical environment and human settlement.

Sociology is the systematic study of relationships among people. Sociologists assumed that behaviour is influenced by people's Social, political, occupational, and intellectual groupings and by the particular settings in which they find themselves at one time or another. Sociologists differ in their approach. Their three major choices are: Functionalism, Conflict and Interactions. Sociology's vast subject matter can be identified as a Study of people, where they collect, how they socialize and organize, whom they include in and exclude from their groups, what they do to their environment, when they confront formulas for control, such as politics, law, finance, religion, education, and social pressures.

Shanker (2006) in Gajere (2016) observed that a variety of subjects are related to Social Studies and the concepts which the subject draw from this multiplicity of disciplines help to improve the study of human beings which is the main focus of Social Studies. This is because the disciplines Study man in totality rather than fragments. The sociological concepts applied in Social Studies helps the students to understand that every society develops a system of roles, norms, values and sanctions which guide the behaviour of individuals and groups within the society. It also helps the learners to acquire the knowledge that every society develops a system of social control. More so, it exposes the learner to the fact 
that the Social environment in which a person is reared and lives has a profound effect on the personal growth and development of the individual.

Economics is the study of the ways in which men and women make a living, which is the most pressing problem most human beings face. It considers the social organization through which people satisfy their wants for scarce goods and services. Its subject matter is often summarized as: Production, Distribution and Consumption. Some of the topics includes: Supply and demand, Monetary and fiscal policy, Costs, Inflation, and Unemployment. Economics seeks to explain, guide, and predict social arrangements by which we satisfy economic wants.

Rodney (2002) in Gajere (2015) asserted that economics concepts enable the Social Studies Students to see human behaviour from a unique perspective. The integration of some concepts helps learners since human wants are scarce. The knowledge of this course will enhance the student's ability to make choices and apply the principle of opportunity cost. This will also expose the Students to idea of interdependence among individuals, communities, states and nations in relation to specialization in production.

History is the study of past events. It is a Social Science in the sense that it is a systematic attempt to learn about and verify past events and to relate them to one another and to the present. Every event has a historical context within which we commonly say the event must be studied. The subject matter of history is everything that has already happened. The study of history involves: Identifying, Classifying, Arranging and Patterning. The study of history is: Imposition of order, Appreciation of variety, Possibilities of prediction, Realization of limitation. History as a discipline is an important component in Social Studies because it exposes the learner to the past, the present so that the future can be predicted. It helps to shape and sharpen human existence in the society. This will assist the students to understand the evolution of man from homo habilis to homo erectus and homo sapiens.

Anthropology is the study of the relationship between biological traits and socially acquired characteristics. Sometimes called the Study of humans, it consists of two broad fields: Physical anthropology and Cultural anthropology. Some of the concerns of physical anthropology include Influence of evolution of natural environment on the physical characteristics of humans. Human evolution: how modern Homo sapiens evolved from earlier species some of the concerns of cultural anthropology are: Archaeology or the remains of extinct civilizations that left no written records, Organization of preliterate societies, Characteristics of subgroups or subcultures within contemporary society. Among the topics that interest anthropologists are excavation of formerly inhabited sites, fossils, the gene pool, technology and artifacts, linguistics, values, and kinship

Morris (2004) cited in Gajere (2015) maintained that concepts in anthropology assist Social Studies students with the opportunity to have key insights into and understanding of what it takes to be human. In the same vein Jarolimek and Parker (1993) are of the view that the knowledge of anthropology in Social Studies enable the students learn about beliefs, values and traditions of other people and appreciate them. There is much in the Social Studies curriculum that is anthropological in content. Indeed, the unified concept of Social Studies has a closer kinship to anthropology in terms of its attempt to deal with the totality of Social phenomena than it does to any other Social Science (Jarolimeketal 1993).

\section{Conclusion/ Recommendations}

Social Studies being an interdisciplinary integration of Social Science and humanities, which promote citizen participation in problem solving, value decision making geared towards the development of citizenship skills on critical Social matters. The components of Social Studies are drawn from different disciplines that help to make up the subject Social Studies. It interdependent had it strands and contents from other related disciplines. The teaching and learning of Social Studies had help in promoting the acceptance of cultural diversity which mostly focus on major events of human race. These had helped in developing democratically minded citizens who are loyal, patriotic, and open to criticizing the government constructively.

One of the challenges that threaten this relationship is that some people particularly those who are not in Social Science Education feels that Social Studies is synonymous with Social Science. They are two distinct areas of study. More over those who Studied either of the Social Sciences feels they can teach Social Studies at the secondary school level. Whereas it is only the Social Studies Education practitioner that can teach the subject effectively because of the training acquired. Based on the review so far done it was recommended that only those who are Social Studies practitioners should be allow to teach the course at any level of our educational institution as to bequeath a benefiting legacy for our generation yet unborn.

\section{References}

i. Aliegba, E. T (2004). The humanities and social-economic development in Nigeria. A critical evaluation. FASS: Journal of Arts Seminar 2.

ii. Ausburg, T (2006): An Introductory to Interdisciplinary Studies. New York: Kendall/ Hunt Publishing

iii. Edinyang, S., Unimke, S., Ubi, I., Opoh, F. \& Iwok, A. (2015). Historical foundation of social Studies. Calabar:

iv. Francis, M. (2008): Principles and Application of Elementary Social Studies. U.S.A.:

v. Gajere, H. P. (2015) Historical Development of Social Studies Education and its Relationship to others allied disciplines. In M.T. Mu'azu (Ed). Contemporary Issues in Social Studies Education in Nigeria. Kaduna: Image prints Publishers.

vi. Hornby, A. S. (2006) Oxford Advanced Learner's Dictionary 7th edition Oxford University Press.

vii. Irikana, G. J. \& Ibeh, H.C. (2014). Social Studies Education: An introductory text. Port Harcourt: Alheri Books.

viii. Jarolimek, J \& Parkev, W. C. (1993). Social Studies in Elementary Education 9th ed. New York: Macmillan Publishing Company. 
ix. Joseph, K. (2008). Connecting Geography to Social Studies. U.S.A:

x. Lawal, M. B. (2002a). Globalisation and Nigeria's natural heritage: A curse or a blessing SOSSAN (2)2.

xi. Lawal, M. B. (2002b). Citizenship Education: A general studies text for tertiary institutions. Lagos: Leo prints.

xii. Morris, P. (2004). Attachment across the gift cycle. London: Rutledge.

xiii. Meziobi, K.\& Meziobi, C. (2016). Social Studies \& Social Science: A book of Reading, Owerri: Acadapeak Publishers

xiv. Mezieobi, K. C. (2016). Social studies: Concepts, Historical Background and Constituents. In Mezeiobi, K. A. \& Mezieobi, K. C. (Eds). Social Studies and Social Sciences: A book of readings. Owerri: Acadapeak Publishers.

xv. McQuail, D. (2005). McQuail's Mass Communication Theory (5th Edition). London: Sage.

xvi. National Council for Social Studies (1992): Expectations of Excellence Curriculum Standards for Social Studies. Washington, D. C.

xvii. Ogunbameru, A. K (2006). Man and His Social Environment. Spectrum, Book Ltd.

xviii. Okpaga, A. (2013). Invigorating the social science for national development: The challenge for Nigeria in the 21stcentaury. In IAUE Rivers Social Science Forum 12(6), 1-26.

xix. Rodney, W. (2002). How Europe under developed Africa. London: Boggle L'overtime Pub.

xx. Saul, M. (2011). Simply psychology; Retrieved from www.simplypsycology.org

xxi. Shanker, R. (2006). Diversity and development. Development express 96-05 Canada: CIDA.

xxii. Slater, Lauren, (2004). Opening Skinner's Box: Great Psychological Experiments of the Twentieth Century. New York: Norton

xxiii. http:/ / www.education.com/ reference/ article/ definitions-social-studies/

xxiv. www.socialstudies.org/ princilesforlearning

xxv. www.ncss.org

xxvi. Wikipedia the free Encyclopedia Retrieved (2015)

xxvii. Zarrillo, J (2013). Teaching Elementary Social Studies Principal and Application. USA. 